\title{
Ménétrier disease
}

INSERM

\section{Source}

INSERM. (1999). Orphanet: an online rare disease and orphan drug data base. Ménétrier disease. ORPHA:2494

Ménétrier disease (MD) is a rare premalignant hyperproliferative gastropathy characterized by massive overgrowth of foveolar cells in the gastric lining, resulting in large gastric folds, and manifesting with epigastric pain, nausea, vomiting, peripheral edema and, less commonly, anorexia and weight loss. 